\title{
CONTROVERSIES
}

\section{What makes a parent? It's not black or white}

\section{G Fuscaldo}

$\mathrm{T}$ he advent of IVF and advances in reproductive technologies largely reflect the importance in our society of biological parenthood and genetic kinship. As illustrated in the controversy piece by Merle Spriggs, ${ }^{1}$ however, the same technology has confused our understanding of what makes a parent.

An embryo mixup in Britain has resulted in a white couple giving birth to two black twins. Genetic tests have established that the wrong sperm was used to inseminate the ova of the white woman who gave birth to the twins. The two couples involved are apparently both seeking custody. Who should have parental rights and responsibilities for the twins?

While once it may have been obvious who a child's parents were and who had obligations and claims with regard to children, the separation of genetic, gestational, and nurturing roles now makes it impossible to "discover" who is the real parent. As Ruth Macklin points out, the question: "Which role should entitle a woman to a greater claim on the baby in the case of a dispute?" is a moral question which cannot be answered by discovery, say through a blood test, but is a matter for decision. ${ }^{2}$ Which are the morally relevant factors and which have the greater moral weight with respect to claims over children? The same questions plague child custody disputes following disagreements between gestational surrogates and commissioning parents, same sex partners and gamete donors, and adoptive versus biological parents.

Many authors have grappled with these questions and the literature reveals at least four different accounts for the basis of parental rights and duties.

\section{BIOLOGY}

Perhaps the most intuitively appealing accounts of what defines parenthood and the most historically prominent are biological and reflect the view that a child belongs to, or is the flesh and blood of, its biological parents. ${ }^{3}$ Difficulties arise in disputes between genetic and gestational parents because both have a biological investment in a child of their union. While the size of the physical contribution from the gestational parent is certainly greater than that from the progenitors, the fact that children share their genetic parents' blueprint, and that of a long line of kin, is also claimed to be significant. ${ }^{4}$ Arguments over the relative importance of different biological investments in children (size $v$ type) have failed to elucidate which factor is overriding and indeed why either entails "ownership" or parental rights and duties.

\section{CONVENTION}

It is often argued that in modern individualistic societies we have overemphasised the importance of biological relatedness. Anthropologists remind us that there exist many cultural groups with different parenting conventions-for example, where fosterage and surrogacy are not uncommon or where children are seen as a communal responsibility. ${ }^{6}$ Even in our own culture it is argued that the many successful examples of couples who adopt or form blended families following divorce, show that biology is not the sole or the most important determinant of parenthood. ${ }^{7}$ But the problem with a cultural account of parenthood and the apparently intractable nature/ nurture debate, is that it is not at all illuminating in terms of who should have parental rights in the event of a dispute which challenges the current convention, as does the latest IVF mixup.

\section{CAUSE}

A more prescriptive account for determining parenthood appeals to the claim that parents have rights and duties towards their children because they have caused them to exist. ${ }^{8}$ This is the type of reasoning that is used to justify paternity testing to assign child welfare payments to genetic fathers in the case of an unintended pregnancy. Although a causal definition of parenthood conforms with our moral intuitions with regard to recalcitrant fathers it does not follow that only a child's genetic parents cause it to exist. It proves quite difficult where third parties are involved to explain who is the cause of a child's existence. A causal account of parenthood fails to distinguish between genes, gestation, and intention since all are involved in the existence of a child, even if not all contribute the most proximal or essential feature.'

\section{CHILDREN'S WELFARE}

Attempts to assign parental rights and duties on the basis of what is in the best interests of children are also unsuccessful in resolving disputes between genetic, gestational, and intended parents. There is much current debate about the need for a child to know and be raised by his or her genetic parents. ${ }^{10}$ Evidence in support of claims that children raised in traditional genetically related families achieve better outcomes, has been presented across a range of criteria, including emotional and psychological identity, and educational outcomes. ${ }^{11}$ To date this evidence remains unconvincing. A growing body of evidence is also available denying these claims and in support of the view that it is the quality of nurturing provided rather than the biological or ethnic relationship or gender balance in the rearing family that is important for children's welfare. ${ }^{12}$

What is clear is that many different features are sufficient to establish at least a prima facie claim to parenthood, but a coherent position on which of these is overriding in the case of competing claims has yet to emerge. It may be that this enterprise is doomed to fail because attempts to weigh up competing claims for parenthood are constrained by the historical and legal norm that a child have two, and only two parents (of the opposite sex). ${ }^{13}$ Clearly for many people genetic and gestational parenthood are very important, as evidenced by the great lengths to which they will go to achieve it. At the same time the meanings attached to raising unrelated children for those who undertake this, are no less profound. Perhaps it is time to relinquish the view that genetic, gestational, and social parenthood are competing positions. We could align the social facts with an acceptance of the new scientific facts - that a child can have many different parents.

In the case of the IVF mixup-parenthood is not black or white, but-black and white. 


\section{Author's affiliations}

G Fuscaldo, University of Melbourne, Australia

Correspondence to: G Fuscaldo, Centre for The Study of Health and Society, University of Melbourne, 209 Grattan Street, Parkville, Victoria 3010, Australia; g.fuscaldo@pgrad.unimelb.edu.au Need full postal address

Accepted for publication 28 October 2002

\section{REFERENCES}

1 Spriggs M. IVF mix up: white couple have black babies. J Med Ethics 2003;29:65

2 Macklin R. Artificial means of reproduction and our understanding of the family. In: Howell JH, Sale WF, eds. Life choices: a Hastings Center introduction to bioethics. Washington DC: Georgetown University Press, 1995: 294.

3 Hall B. The origin of parental rights. Public Aff Q 1999;13:73-82, for a genetic account of parenthood based on self ownership of genetic material.

4 Discussed in Alpern KD. Genetic puzzles and stork stories: on the meaning and significance of having children. The ethics of reproductive technology. Oxford: Oxford University Press, 1992.

5 A problem discussed in Silver LM, Silver SR. Confused heritage and the absurdity of genetic ownership. Harv J Law Technol

1998;11:593-618 at 600; and Kolers A, Bayne T. Are you my mommy. J Appl Philos 2001;18:273-85.

6 For examples see Sault NL. Many mothers, many fathers: the meaning of parenting around the world. Santa Clara University Law Review 1998;36. www.scu.edu (accessed 23 July 2001). See also Donner WW. Sharing and compassion: fosterage in a Polynesian society. $J$ Comp Fam Stud 1999;30:703-30 and Stone L. Kinship and gender Boulder, CO: Westview Press, Harper Collins, 1997.
7 Bartholet E. Family bonds, adoption and the politics of parenting. Boston MA: Houghton Mifflin, 1993.

8 As argued by Nelson JL. Reproductive ethics and the family. New Zealand Journal of Bioethics 2000;1:4-10 and Nelson JL. Parental obligations and the ethics of surrogacy: a causal perspective. Public Aff Q 1991;5:49-61. See also Hill JL. What does it mean to be a "parent"? The claims of biology as the basis for parental rights. New York Univ Law Rev 1991:66:353-420 for an account of parenthood based on intent.

9 For discussion of the problems with causal accounts of parental duties and rights see Blunstein J. Procreation and parental responsibility. J Soc Philos 1997;28:79-86; and reference 5: Kolers A, Bayne T.

10 For examples see Turner AJ, Coyle A. What does it mean to be a donor offspring? The identity of adults conceived by donor insemination and the implications for counseling and therapy, Hum Reprod 2000;15:2041-51; and Frith L. Gamete donation and anonymity. Hum Reprod 2001; 16:818-24.

11 Muehlenberg B. The case for the two-parent family. Melbourne: The Australian Family Association, 2001, and The historicity and universality of the natural family. Melbourne: The Australian Family Association, 2000 available through the association, www. family.org.au

12 For a summary of research examining how children are affected by not living with two biological parents see Cherlin AJ. Going to extremes: family structure, children's wellbeing, and social science. Demography 1999;36:42 1-8. See also Baetens P, and. Brewaeys A. Lesbian couples requesting donor insemination: an update of the knowledge with regard to lesbian mother families. Hum Reprod Update 2001;7:512-19. Also Brewaeys A. Review: parent-child relationships and child development in donor insemination families. Hum Reprod Update $2001 ; 7: 38-46$. For discussion of the significance of racial mismatches between parents and children see Fogg-Davis $\mathrm{H}$. The ethics of transracial adoption. New York: Cornell University Press, 2002.

13 As argued by Alta Charo R. Biological determinism in legal decision making: the parent trap. Texas J Women Law 1994;3:265-306.

\section{JME reviewers 1998-2002}

We would like to thank assessors who have helped on editions of the journal over the last five years. Their advice, guidance, and support is greatly appreciated. A full list of names is available on our web site www.jmedethics.com, under the heading electronic pages.

During the last nine months the journal has moved to an internet based tracking system. If you assessed a paper during the transition period it may be that your name does not appear in that list, for which we apologise. If this is the case, please let us know. If you have not previously assessed an article for the journal and would like to do so, please contact the editorial assistant (Ruth Coster; jme@BMgroup.com) with your contact details and areas of expertise and she will be pleased to add your name to our database. 